International Journal of Trend in Scientific Research and Development (IJTSRD) @ www.ijtsrd.com eISSN: 2456-6470

\title{
Burzahom (Burzohama) a Neolithic Site in Kashmir
}

\author{
Sartaj Ahsan Bhat1, M C Dubey² \\ ${ }^{1}$ M. Phil Research Scholar, 2 Professor \\ Department of History, Mewar University, Rajasthan, India
}

\begin{abstract}
Kashmir perhaps possess an authentic account of its History from the very earliest period. The Neolithic site of Burzahom throws a light on the different phases of the earliest history of Kashmir. The Burzahom site is a prehistoric settlement in the village of the same name in the Valley of Kashmir, a valley located between the Karakoram and the Pir Panjal Range. It is located between $34^{0} 10^{\prime} \mathrm{N}$ and $73^{0} 4^{\prime}$ ' E. It is 16 kilometers (9.9 miles) to the northeast of Srinagar on the Naseem-Shalimar road. The elevation of the site is 1,800 meters $(5,900 \mathrm{t})$ above sea-level. It is the northernmost excavated Neolithic site of India. The site is on an ancient Pleistocene lake bed ${ }^{1}$.The location is in a high terrace which is part of the floodplain of the Jhelum River and has Karewa soil (clay) formation. The site has a commanding view of the Dal Lake which is about 2 kilometers (1.2 miles) away. In the Kashmiri language 'Burzahom' means " birch", a tree species (that generally grows in the elevation range of 3,000 to 4,200 meters $(9,800$ to $13,800 \mathrm{ft}$.) in the Himalayas), which is found in the excavated housing area in the form of roofing material, and thus confirming the existence of the tree even in the pre-historic Neolithic times ${ }^{2}$.
\end{abstract}

\section{Keywords: Neolithic, Karewa, Pleistocene, Terrace, Floodplain, Karokaram}

\section{INTRODUCTION}

The first excavation at the Burzahom site was a limited exercise in 1936, carried out by the Yale-Cambridge Expedition headed by Helmut de Terra and De Thomas Thomson Paterson ${ }^{3}$.The Frontier Circle of the Archaeological Survey of lndia made detailed investigations of the site between 1960 and 1971; these were carried out by T.N. Khazanchi and his associates ${ }^{4}$. The extensive excavations done at this site, unearthing stratified cultural deposits, were the first of their type in Kashmir. In 1944, Mortimer Wheeler, Director General of the Archaeological Survey of India had conducted the first stratified archaeological excavations on the lines of geological model at other sites 5 . Based on a similar model the Burzahom site has been named as the Northern Neolithic Culture in view of its distinctive structural features with profusion of tools made of bones and stones and tools representing the ritualistic practices ${ }^{6}$. Skeletal remains of Neolithic people found at Burzahom are similar to those found in Harappa of the Indus Valley Civilization?.

The management and protection of the Burzahom site, including the buffer zones, are under the jurisdiction of the Archaeological Survey of India and the State Department of Archaeology conforming to the Ancient Monuments and Sites Remains Act 1958 (Amended in 2010). This site was

${ }^{1}$ Buth, G. M and R.N. Kaw. Plant Husbandry in Neolithic Burzahom, Kashmir, Current Trends in Geology, Climate and Geology of Kashmir and Central Asia. New Delhi, 1985, p43 ${ }^{2}$ Singh Upinder, A History of Ancient and Early Medieval India. From the Stone age to the $12^{\text {th }}$ Century Pearson Education 2008, p.111.

${ }^{3}$ Banday Ajaz Prehistoric Kashmir, Archaeological History of Paleolithic and Neolithic Cultures, Dilpreet Publishing House New Delhi, p.74.

${ }^{4}$ Shali S.L, Kashmir history and Archaeology Through the Ages, Indus Publication Company, New Delhi, p64-66.

5Ibid, p. 70-71.

${ }^{6}$ Banday Ajaz Prehistoric Kashmir, Archaeological History of Paleolithic and Neolithic Cultures, Dilpreet Publishing House New Delhi, 86-87.

${ }^{7}$ Pande B.M, Neolithic Hunting Scene on a Stone Slab from
Burzahon, Kashmir, Asian Perspective, Vol. XIV, pp 134-138. nominated on 15 April 2014 for inscription as a UNESCO World Heritage carried out Site, and is yet to be approved. The excavation at Burzahom was in both vertical (depth wise) and horizontal directions, the depth provided the stratification features, while the phasing of each stratification was provided by the horizontal excavations. Four periods of continuous occupational sequence at the site were documented over a period of 11 years of investigations from 1960 to 1971 . These are: Periods 1 and Il of the Neolithic (Period I is called aceramic and Period II is called ceramic) origin, particularly characterized by dwelling pits (the largest measuring 2.74 meters ( 9 feet ) at the top to 4.75 meters ( 15.6 feet) at the base at a depth of 3.95 meters (13.0 feet); Period III of the Megalithic sequence noted by the free standing large stone ${ }^{8}$.

\section{Description of the Site and Archaeological findings:}

The Neolithic Site of Burzahom, in the district of Srinagar, India brings to light transitions in human habitation patterns from Neolithic Period to Megalithic period to the early Historic period. From transition in architecture to development in tool-making techniques to introduction and diffusion of lentil in the north-western India, the site of Burzahom is a unique comprehensive story teller of life between 3000 BCE to 1000 BCE The remains of the site document the gradual change in the nature of dwelling spaces among early societies. From subterranean dwelling pits, the evidences in the site show the emergence of mud structure, there on mud bricks constructions on level ground. ${ }^{9}$ The range of tools recovered from the site shows the evolution in tool making Neolithic men skilled hunters and their knowledge in applying the implements for cultivation. The subterranean pit dwellings of Neolithic men (Aceramic Neolithic/Period I) were cut into the natural soil usually dug out with long stone Celts, the cut marks of which can still be traced. The pits were circular or oval in plan, narrow at the top and wide at the base having (wooden) post holes on the ground level suggesting a birch cover as a protection against

${ }^{8}$ Sharma S.P. Kashmir through Ages, RBSA Publishers Jaipur, p16 
the harsh weather. Some pits were shallower, with depth of about $91 \mathrm{~cm}$ (as opposed to 3.95 meters depth) and were possibly either storage pits or those used as dwellings during warmer period. Stone hearths have also been found at ground levels, near the mouth of pits, showing that habitation activities were also at the ground level. Ascribed to the same era are subterranean dwellings of quadrangular section, covered by a layer of birch, with a centrally placed stone or clay hearth and storage pit. The several pottery shards of steel grey, dull red, brown or buff have been recovered from the pits as one of the material remain. Crude in finish, the continuity of these types of crude pottery can be seen in today's Kashmir. Apart from pottery, bones and stone tools like harpoons, needles with or without eyes, awls used probably for stitching skins, spear-points, arrow heads and daggers for hunting game, scrapers for treating skins, stone axes, chisels. adzes pounders, mace-heads, points and picks were used by the Neolithic settlers n this period. Apart from stone, antlers were also used for tool-production. ${ }^{10}$ This layer is marked by absence of any burial system as well a cultivation. In the next stage (Ceramic Neolithic/Period II ) structures in mud or mud bricks with regular floors made of rammed karewa soil, often reusing erstwhile pits by filling in with mud and finished by plastering a layer of mud covered with a thin coat of red ochre as well as timbre showing evolution in construction techniques. This layer also yielded few copper arrowheads, black-ware pottery, a dish with a hollow stand, globular pot, jar, stem with triangular perforations ${ }^{11}$, a funnel- shaped vase a wheel made red ware pot which contained 950 beads, beads of agate and carnelian and painted pots, the latter could have been an evidence of a trade. One of the unique finds of this layer is a red-ware pot with a horned figure painted on it. The stone and bone-wares of this period show distinct development in finish. The implements recovered the rectangular harvesters with a curved cutting edge with two or more holes on either side, double edged picks in stone, long sized needles with or without eye and the unique borer on a long hollow bone, like the cobbler's porker.An instance of art-producing behavior of Neolithic men is witnessed in the site where an engraved stone depicting a hunting scene, with human, a dog, the sun path diagram has been found. The earliest remains of pit burial is ascribed to the Period II. Oval pits were dug into the house floor and were plastered with lime and bodies were placed with red-ochre on the bones. Skeletons were also found in crouched positions often without any grave furniture while in some instances accompanied with animal skeletal remain ${ }^{12}$. Seven evidences of complete and four incomplete evidences of trepanning of human skulls have also been noted. One of the interesting recovered is that of dogs and antler's horn ${ }^{13}$. The Neolithic period is followed by Megalithic culture associated with the erection of massive stones or menhirs, most probably as commemorative establishments. The material culture recovered constitutes of a gritty red ware pottery, manufactured in potter's wheel, metal objects and few tools made of bone and stone continued.

10Ibid p.70

11Pant R.K, Microware Studies on Burzahom, Neolithic, Tools Kashmir Published in "Man and Environment" Vol.3, 1979, p.11-18,poker.

${ }^{12}$ Shali S.L, Kashmir History and the Archaeology Through the Ages, Indus Publication Company, New Delhi, p.92. ${ }^{13}$ Banday Ajaz Prehistoric Kashmir, Archacological History of Paleolithic and Neolithic cultures, p.98
Rubble structures associated with the Megalithic men have also been found. The last level of activity at Burzahom is ascribed to the early historical period and is dateable to $3^{\text {rd }}$. $4^{\text {th }}$ century AD. Mud brick structures, pottery manufactured in a wheel and a few metal objects have been found from this era. The practice of agriculture has been established through the tools and finding of paleo-botanic analysis. Periods I and II provided evidence for wheat, barley and lentil cultivation. The presence of lentil in the Burzahom Neolithic further explains that the people of Burzahom had wide contacts with Central Asia, a critical evidence of the human movement through mountain passes into the Kashmir valley. Justification of Outstanding Universal Value the Neolithic Site of Burzahom, in the district of Srinagar India brings to light transitions in human habitation patterns from Neolithic Period to Megalithic period to the early Historic period. From transition in architecture to development in toolmaking techniques to introduction and diffusion of lentil in the north-western India, the site of Burzahom is a unique comprehensive story teller of life between 3000 BCE to 1000 BCE.

The Neolithic pottery at Burzahom provides a detailed insight into the material equipment of the Neolithic people when they even did not have invented the technique of pottery manufacturing. The results of excavations have provided dynamics of interchange of ideas between central Asia and South West Asia through the valley of Kashmir which acted as a bridge between higher Himalayas and beyond on the one hand, and Gangetic plains and peninsular India on the other hand during the third millennium B.C. The interaction of local and foreign influences are demonstrated by the art, architecture, customs and rituals as also possibly by the language demonstrated by some graffiti marks on pottery and others ${ }^{14}$.

The core aspects of the Burzahom Neolithic seem to have originated and organically evolved on the soil of Kashmir, and bear an exceptional testimony to a cultural tradition which has now largely disappeared. The nominated property with its entire cultural equipment range has potential for future excavation and other avenues of research which is surely ripe with new set of information throwing a welcome light on the formative stages of culture and civilization in this part of the world.

Sometime at the turn of the fourth millennium BCE, the Neolithic Burzahom appears to the major centers of prehistoric man's activity in Kashmir. The detail study of the material culture, paleo-climate, flora, and fauna, micro- wear studies, and other multidisciplinary studies has provided an opportunity to understand and analyze the interaction of the Neolithic population of Burzahom with the Himalayan hinterland and the riverine sites of West Asia. Statements of authenticity and/ or integrity Authenticity: The remains in the Neolithic site of Burzahom narrates the cultural sequence of human habitation from 3000 BCE to 1000 BCE (Periods I and II belong to the Neolithic period, Period III the Megalithic period, and Period IV to the Early Historical period or Post-megalithic period). integrity: The entire site retains its physical integrity and is still set in a landscape that is reminiscent to the natural setting of the Neolithic men approximately in 4th millennium B.C. Each pit is protected

${ }_{14}^{14}$ Pande B.M. Neolithic Hunting Scene on a Stone Slab from Burzahom, Kashmir, Asian Perspective. Vol. XIV pp. 136 
and retains its physical stability, demonstrating types of spaces devised by Neolithic society. The property and buffer zones are protected and managed by the Archaeological Survey of India and the State Department of Archaeology under the Ancient Monuments and Sites Remains Act' 1958 (Amended in2010).

\section{Peculiarity of the Site:}

By 2,000 BC, the Neolithic people of Burzahom started to live in mud huts at ground level, and by this time, there is also evidence of multiple burials, usually under house floors or in the compounds. Red ochre was smeared on the bodies before burial. Apart from human burials animals were sometimes buried along with humans or in separate graves. The buried animals included wild animals like wolves, ibex and antlered deer and domesticated animals like dogs, sheep and goats. Not long after, the inhabitants entered what is known as the 'Megalithic Phase', which is associated with the setting up of menhirs or single standing stones, which can still be seen in Burzahom today.

The overall economic level at Burzahom seems to be that of the hunters and food gatherers, with the Neolithic folk at Buzahom practicing rudimentary cultivation that is attested by harvesters, round perforated stones used possibly as weights for digging sticks, etc., discovered at the site. Mention may also be made here of the evolutionary sequence at Burzahom and the other sites in Kashmir valley, which clearly reveals not only the dovetailing of the Neolithic with the Megalithic but also points to the emergence of megalithism in Neolithic times in the Kashmir valley ${ }^{15}$.An interesting discovery made at.

Burzahom was a carved stone slab that shows two hunters hunting a stag, while twin suns shine in the sky. The presence of two similar suns in the sky is a mystery. Some researchers believe that the Neolithic artists depicted two suns to indicate the duration of the hunt (e.g. two days), while a far more exotic theory has been proposed by a team of astronomers who believe that the scene represents the ancient night sky with the two suns actually representing the moon and a supernova, while the hunters and the animals represent constellations like Orion and Taurus. The stone slab formed part of a rectangular structure made of stone slabs and rubble belonging to the second phase of the Neolithic culture at the site. The slab, with engravings, stood on its edge in an inconspicuous place, and seems to have been reutilized. In all probability, the slab was not originally intended to be a part of the structure despite the fact that the engraving had been facing the interior. The structure itself was built on an oblong plan, inside which was found an infilling of fine yellowish sand. The purpose of this extant structure, represented by only one course, is not difficult to ascertain, nor is it possible to establish any relationship between the structure and the slab bearing the hunting scene. The stone slab is flat on both faces, the carved side being smooth compared to the un-carved one. It is irregularly cut, with a maximum width of $70 \mathrm{~cm}$. toward the top it is partially damaged, as a result the uppermost part of the scene is lost to a small extent. However, the break is certainly not a fresh one, and perhaps this very break might have resulted in its subsequent reuse as an ordinary slab in the structure. The hunting scene is incised on the upper halt

15Ibid page 460-461 of the stone, and has a maximum height of $48 \mathrm{~cm}$, the graving itself covers an area of $48 * 27 \mathrm{~cm}$ and is divided into two registers. The scene depicts two human figures hunting a stag, one of them attacking it from the front with a bow and an arrow having already pierced through the chest of the anima. This figure is shown in an unusual posture for an archer, that is, with the right knee placed on the ground while drawing the bowstring with his right hand and releasing the arrow with the left. The bow appears to be of the single segment type so commonly used in Neolithic times $^{16}$.The figure has a height of $12 \mathrm{~cm}$. The other figure is attacking the animal from behind with a long spear which has almost pierced through the body of the animal. This figure stands akimbo, thrusting the spear with its upraised right hand, and measures to a height of $14 \mathrm{~cm}$ from top to toe. The principal figure in the scene is that of the stag, which occupies the central position. The animal is shown with a spotted or striped body and many-branched antler. It measures $14 \mathrm{~cm}$ in length and $13 \mathrm{~cm}$ in height. In the upper register are shown a dog and two symbols. The height and length of the dog, which evidently is a member of the hunting party, are both $6 \mathrm{~cm}$, and it has distinctly long straight ears, long legs, and a curved tail. The symbols, which are alike comprise two concentric circles, with sixteen radiating lines all around. One of these, on the right, is partially damaged. The entire human and the animal figures depicted in the scene can be identified because of the distinct delineation. For instance, of the two human figures, the one facing the stag is a male and the other behind the stag is a female, the male figure (facing the stag) has been shown with exaggerated genitals between the legs, while the other figure (behind the stag) can be identified as a female on the basis of the breasts seen clearly in her contour-profile and the skirted dress she is wearing. The identification of the latter as female is further attested by her attacking posture, in which she has been shown standing akimbo characteristic of a female-while thrusting the spear into the animal. It is rather unusual to have the representation of a female with a spear. Further this figure is also shown without the representation of the genitals, which are depicted quite clearly in the case of her male companion. The figure of the central animal is of the stag (Cervuselaphus), the excavation itself yielded the skeletal remains of the animal. That it is a male is proved by the antler and the representation of the genitals, again of an exaggerated size. The dog seems to be a domesticated one and trained in accompanying the hunting party. Representation of the genitals of this animal also shows that it is a male. The two symbols on the topmost part possibly represent the sun, one of which perhaps represents the day of the hunt and the other the day of the successful return ${ }^{17}$. Significant in the context of the Burzahom, hunting scene is Campbell's interpretation, which is as follows: "The crucial point of the Pygmy ceremony was that the rite should take place at dawn, the arrow flying into the antelope precisely when it was struck by a ray of the sun. For the sun is in all hunting mythologies a great hunter. Nor has the hunter killed the beast as a personal willful act, but according to the provisions of the Great Spirit and in this way nothing is lost"18.

\footnotetext{
16Rausing Gad, The Bow, Some notes on its Origin and Development, Series, No 8, p 35-51.

${ }^{17}$ Campbell Joseph The Masks of God Primitive Mythology Secker \& Warburg, Page 296-97.

18Ibid, p 298
} 
We also know of the belief among the Neolithic peoples elsewhere that the sun has the power to multiply the game ${ }^{19}$, and that the cults of the sun and of fertility merge notably with that of the stag20. Solar symbolism is fairly common in Neolithic times ${ }^{21}$ and heliolatric religion grew with the adoption of a near-settled life and agriculture, which the remains from Burzahom substantially attest.

Another unique finding from Burzahom, was seven complete and four incomplete evidences of trepanning of human skulls. Cranial surgery, known as trepanning or trepanation, is one of practices and is known to have begun in the Neolithic era. It involves drilling a hole in the skull of a living person to cure illness such as convulsions, headaches, infections or fractures. One of the skulls found at the Burzahom displayed evidence of multiple trepanation or drilling holes. There are six completed perforations resulting from eleven attempts over at least four successive sittings with the woman either living or recently deceased. Some scientists believe that the trepanation was done with the sole purpose of taking out round skull pieces for ritual offerings or magico- religious practices, while others insist that it was a clear case of surgery performed for predominantly medical reasons on the woman while she was still alive. Amazingly, many cases of ancient trepanation appeared to be successful as there was evidence of both the original wound and the surgical wound having been healed.

The term 'megalith' is derived from Greek megas', which means great and lithos' meaning stone.

As the nomenclature suggests, the 'megaliths' refer to the monuments built of large stones. But all monuments constructed of big stones are not megaliths. The term has a restricted usage and is applied only to a particular class of monuments or structures, which are built of large stones and have some commemorative or ritualistic association except the hero stones or memorial stones. In other words, the megaliths usually refer to the burials made of large stones in graveyards from the habitation area. The main concentration of the megalithic cultures in India was the Deccan, especially south of the river Godavari. However, large-stone structures resembling some of the usual megalith types have also been reported from some places in North India, Central India and Western India. These include-Seraikala in Bihar, Deodhoora in Almora district and Khera near Fatehpur Sikri in Agra district of Uttar Pradesh, Nagpur, Chanda and Bhandra districts of Madhya Pradesh, Deosa, 32 miles east of Jaipur in Rajasthan. But since neither the excavation nor a reliable surface-examination of these monuments has so far been carried out, it is difficult to say if and how far they are connected with the megaliths of the Deccan. Similar monuments or structures are also found near Karachi in Pakistan, near Leh in the Himalayas and at Burzahom in Jammu and Kashmir. However, their wide distribution in the southern region of India suggests that it was essentially a South Indian feature which flourished at least for a thousand years, resulting in a variety within the underlying megalithic unity of common origin.

\footnotetext{
${ }^{19}$ Ananti Emanuell, Camonica Valley, 1964, Jonathan Cape, London, p.163

${ }^{20}$ Ibid P.164. Maringer Johannes

${ }^{21} \mathrm{~A}$ Picture Emerges, An assessment of the C-14 Dating Of the Protohistoric Cuiture of Indo-Pakistan Subcontinent Ancielndia, 1962-63, Vol. 18\&19.p 217
}

\section{References:}

[1] Agarwal, D.P the Archaeology of India. London, 19.

[2] Ahad Abdul. Kashmir Rediscovered 2006 Humayun Publishing Company.

[3] Danish Kada Pine Avenue Rawalpora Srinagar 190005.

[4] Ahad Abdul, Kashmir to Frankfurt Adam Publications \& Distributors Pataudi House DaryaGanj New Delhi. 1998.

[5] Anand Kaul Pandit, Archaeological Remains in Kashmir, Digital Library of India. Accessed on 15 August 2015.

[6] Armstrong Keren, A History Of God Vintage Books-1999 (Random House) London U.K.

[7] Bagchi P.C. India and China Munshiram Manoharlal Oriental Publishers 54 Rani Jhansi Road, New Delhi-55.

[8] Bamzai P.N.K. Culture and Political History of Kashmir Volume 1 (1994).

[9] M.D Publications Pvt. Ltd, M.D House 11 Darya Ganj, New Delhi-110002.

[10] Banday Ajaz, Pre Historic Kashmir, Archaeological History of Paleolithic and Neolithic cultures, Dilpreet Publishing House, New Delhi.

[11] Bazaz Prem Nath. The History of Struggle For Freedom In Kashmir (Cultural and Political From the Earliest Time to Present Day) Gulshan Books Residency RoadSrinagar 190001 Kashmir.

[12] Ghosh. A. Indian Archaeology, A Review 1962-63, Archaeological Survey of India, Govt. of India New Delhi 1965.

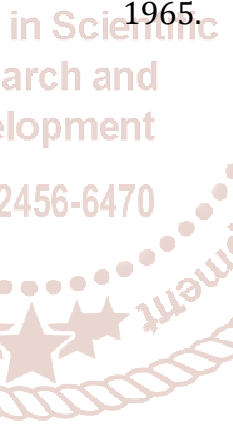

